\title{
Consumer Attitudes Towards New Circular Models in the Fashion Industry
}

\author{
- Zdenka Musova, Hussam Musa, Jennifer Drugdova, George Lazaroiu, \\ Jehad Alayasa
}

\begin{abstract}
The fashion industry ranks among the most resource-intensive and environment-polluting industries. Circularity has been discussed as a solution to these problems. However, the transition towards a circular economy (CE) requires fundamental changes in the behavior and actions of all market entities. Consumer interest in sustainability and circularity can stimulate businesses to become more responsible and to offer circular solutions, and thus create a significant competitive advantage for these firms in a globalized market. This paper examines consumer attitudes towards the new circular models in the fashion industry (e.g. slow fashion, swapping, clothes rent, etc.). Consumer knowledge of these models, consumer willingness to support them as well as a correlation to selected demographic characteristics will be described along with consumer attitudes towards textile products made of waste and recycled material. Results will be introduced from a questionnaire survey carried out in October and November 2019 using the sample of 468 respondents in Slovakia. The obtained data were evaluated using statistical methods (Pearson Chi-Square, Wilcoxon test, Spearman's correlation coefficient). While generally a low awareness of Slovak consumers of new models in the fashion industry was confirmed, the willingness of consumers to engage and support circular solutions was shown, especially among the younger generations. These results show that businesses that react to consumer expectations regarding circularity by offering products and services with environmental benefits may increase their competitiveness.
\end{abstract}

Keywords: circular economy, new circular models in the fashion industry, consumer attitudes, competitiveness JEL Classification: M14, Q56

Received: December, 2020

1st Revision: April, 2021

Accepted: July, 2021

\section{INTRODUCTION}

Turbulent changes which significantly affect the behaviors of all market players mark today's highly competitive global market environment. Consumers negatively influenced by growing problems in the natural environment are increasingly aware of the need for greater responsibility in this area. In taking into consideration consumer expectations in this area, businesses must 
also rethink their strategies to become more sustainable, thus more profitable and competitive. Today the fashion industry has a huge environmental impact, with textile disposal increasingly being seen as a major problem around the world. Fast fashion retailing leads consumers towards more frequent purchasing of textile products and keeping clothing for a shorter time, causing a rise in waste in the textile disposing phase of the industry (Bianchi \& Birtwistle, 2012). The implementation of the principles of the circular economy (CE) in fashion businesses, the promotion of sustainable fashion models, as well as the circular recycling of textile waste products have all been seen as solutions to this problem. Many businesses have already started to incorporate circularity into their practice as a promising way to combine economic success with sustainability.

Consumers have been identified as key economic actors in driving the transition process towards $\mathrm{CE}$, as they can support or hinder the uptake of the new circular fashion models through purchasing, use, and disposal choices. A significant portion of consumers have begun acting more responsibly towards the environment and in doing so have come to emphasize environmental requirements when deciding on and making purchases (Musova et al., 2021). Chekima et al. (2016) have confirmed that the demand for sustainably made products is higher than ever as consumers become more educated and enjoy greater and immediate access to information. Wei et al. (2018) have found that consumers are willing to pay more for "green" and sustainable products. On the other hand, according to Han et al. (2017), an attitude-behavior gap remains between the sustainability concerns of the consumer and their choices regarding sustainable fashion products consumption.

These actualities have forced businesses to concern themselves with sustainable production in the fashion industry, e.g. in terms of the research and design of environmentally friendly innovations (Ulku \& Hsuan, 2017). Fashion businesses who seek to strengthen their competitiveness and improve their market positions cannot afford to lose environmentally-conscious consumers. Firstly, new circular models must be developed before they can be accepted and supported by consumers. A key to the success of any business depends on knowing the consumer, including understanding how the targeted customer makes decisions regarding purchasing and consuming. The needs, desires, motivations, and requirements of the customer must have an enormous influence on the decisions of businesses in the fashion industry all along the design, production, promotion and sales chain. Keeping all of the above context in mind, this article focuses on consumer attitudes towards new circular models in terms of textile production-related practices (e.g. slow fashion, swapping, clothes rent, etc.). The attitudes and motives of consumers as well as barriers which serve to work against positive customer decisions to purchase products made from waste materials are investigated, along with a correlation of these issues to selected demographic variables.

After a brief literature review in the following section, the applied methodology is presented in a description of the research design, sample size, data collection and analytical methods in Section 3. The research results are presented and discussed in Section 4, followed by our conclusions in the last section, including possible lines of future research. 


\section{THEORETICAL BACKGROUND}

The circular economy (CE) is a relatively new concept created to facilitate a societal change towards increased sustainability. Gaustad et al. (2018) state that this change entails rethinking and redesigning production and consumption patterns to avoid negative environmental impacts and preserve natural resources. Suárez-Eiroa et al. (2019) express that the current linear model is not sustainable, as resources are limited. Most of the literature on CE seems to focus on the production side. Less attention has been devoted to how the consumption process and consumers themselves would be affected by CE (Kirchherr et al., 2018). According to Mugge (2018), the CE model in practice should build the competitiveness of economies at the local, national, regional and global level, creating stable economic growth and a healthy environment. The main priority is to achieve the greatest possible conservation and most efficient use of natural resources, which are seen as limited. The prevention and reduction of waste represent an integral part of this shift in design, production and consumption. From the perspective of the individual business entity, in today's highly competitive global environment the implementation of CE principles constitutes an aspect of corporate social responsibility (CSR), considered a tool for building competitive advantage. Through promotion and marketing, the $\mathrm{CE}$ model becomes a strength in which an entity can differentiate itself from competing businesses. The application of the CSR and $\mathrm{CE}$ principles contributes to the improvement of relations with all stakeholders, especially with customers.

Riba et al. (2020) point out that nowadays the textile and fashion industry ranks among the most resource-intensive and environment-polluting industries in most parts of the world. Two characteristics of this global industry are competitiveness and the constant need to update product offers to meet the changing demands of the consumer. Gazzola et al. (2020) note that the fashion industry represents a significant economic force which employs more than 300 million worldwide. According to Souchet (2019), in the last two decades the textile industry has doubled its production and average global annual consumption of textiles has also nearly doubled (from 7 to $13 \mathrm{~kg}$ per person). Consumers globally consume large amounts of clothes and materials as a result of the current "buy-and-throw-away" culture. For the reasons above, it is essential to adopt a more sustainable behavior in the fashion industry in the context of CE principles. Many businesses have already realized the need to reduce waste and have started the recycling of textile scraps, intending to reduce landfill usage as well as to create a new source of materials. Although many textile products and clothing items are recyclable, Camacho-Otero et al. (2019) state that $73 \%$ of the total amount of textile fiber is incinerated and only $12 \%$ recycled or used to produce a new product. At the same time, up to $95 \%$ could be put back into circulation by re-carrying, recycling, or repairing (Henninger et al., 2019).

Many new creative circular practices in the fashion industry are based on cooperation with consumers. Upcycling is a method of re-use in which, after significant modification, a product acquires a new use, creating new value from existing sources (Paras et al., 2019). Fashion swapping is an example of shared consumption, reducing the demand for new textile products (CamachoOtero et al., 2019). In addition to swapping, Henninger et al. (2019) mention other ways in which the consumer becomes a trader: donating unwanted clothing (to a friend, acquaintance or, charity) or selling unwanted items directly. Slow fashion, also guided by CE principles, is a 
lifestyle that reflects care about quality as well as respect for the environment, e.g. by supporting local brands and local designers (thus avoiding long distance transport). At the same time, proponents of the slow fashion movement boycott mass-marketed and seasonal products as well as international textile chains. One specific model is the capsule wardrobe, which consists of a limited amount of clothing that is timeless and easy to combine in various ways. Within the hierarchy of circular solutions being established the fashion industry, the possibility of renting/ leasing clothes for temporary use is also gradually becoming more popular.

A specific area of research in the context of circularity is fashion/textiles made from waste. A radical change in the value supply has emerged which requires increased consumer environmental awareness. Health safety and compliance with environmental standards throughout the product's life cycle are guaranteed by various certificates and eco-labels, which also help consumers make informed purchasing decisions. The perception of fashion products made from waste materials, however, is different. A study by Magnier et al. (2019) has documented low risks (or no risks) in terms of expected quality, functionality, and contamination. Paco et al. (2020) reported negative consumer attitudes towards the reuse and recycling of fashion and textiles due to putative issues of cleanliness, contamination, and previous ownership, as well as availability. According to research by Park \& Lin (2020), other factors (reduced availability, economic risk, product type) are also important for recycled and upcycled fashion products. Differences in attitudes between genders as well as among various age groups of consumers are predictable.

The number of studies on environmentally responsible consumer behavior and environmental attitudes during the past decade has increased. It has been confirmed that consumers have become more reactive, showing more awareness as well as willingness to change behaviors and use alternative products. Despite this, the consumer reactions are often seen as controversial or irrational, and it is difficult to identify the particular justifications for negative attitudes. This has also been confirmed by Henninger \& Singh (2017), who claim that consumer environmental concerns do not always translate into their purchasing behaviors. On the other hand, GreboszKrawczyk \& Siuda (2019) found that environmentally friendly attitudes signal the tendency of consumers to favor (or disfavor) some sustainable behaviors as well as their overall willingness to engage in such behaviors. One study by Wiederhold \& Martinez et al. (2018) even confirmed a direct link between eco-attitudes and eco-behavior. According to Haanpää (2007), there is a wide range of "green" behaviors. Green consumers are usually interested in ecological lifestyles, are environmentally conscious, carefully select products, and are volunteers in various events for environmental protection. In addition, consumers are constantly influenced by social norms guidelines, principles for action, or controls for behavior. For many people, the environmental protection is still an area of uncertainty and unstable attitudes. For this reason, interpersonal communication is necessary, with the aim of building rules of consensus, affirming behavior and attitudes, and establishing social standards and norms to support pro-environmental behavior (Fell et al., 2009).

Active consumer involvement in the activities for environment protection is determined by consumption style and lifestyle as well, which is closely related to socioeconomic variables and demographic background. The differences in perception towards environmental issues caused by demographic factors were confirmed by several studies (Gazolla et al., 2020; Fisher et al., 
2012). Results of studies that compared age groups were more mixed. More consistent results were found for gender. It is also in line with the research of Liobikiene et al. (2017), which found that women are more environmentally friendly and are more likely to act ecologically responsible than men. Concerning the age of a consumer, the younger generations Y (born 1977-1994) and Z (born later than 1995) are characterized by a higher environmental awareness compared to previous generations (Kusa \& Greskova, 2016). Statistically significant variables influencing environmentally responsible consumer behavior in Slovakia (in general) include age, gender, and income, according to previous research by Musova et al. (2021). Mentioned demographic characteristics are important criteria for effective market segmentation in fashion businesses creating sustainable and circular offers. Based on the findings above, the part of the research is focused on testing hypotheses about the dependence of circular consumer behavior and selected demographics in the fashion industry, too.

Insufficient or limited environmental awareness of some Slovak consumers has been confirmed from previous research (e.g. Musova et al., 2021). When purchasing, the environmental factors are not as crucial for them. There is a variety of different consumer attitudes to environmental protection and environmental purchasing behavior. The biggest segment consists of so-called "Sprouts" - consumers who could be the best target group for the pro-environmental activities of businesses. Also, the segment "Greenback Greens" is positively evaluated, which is typical by stronger willingness to pay more for environmentally friendly products. The mentioned environmentally responsible segments represent significant potential for successful adoption of new circular solutions by consumers in Slovakia. Consumers' adopting and supporting new circular fashion models is a new topic, and in the context of current global challenges, intensive research is urgently needed.

The indicated findings were an incentive for us to investigate it in more detail, given the "novelty" of the topic and only the initial limited offer of circular models in Slovak conditions. Businesses need to know whether their offers will be adequately perceived and adopted by consumers. In our opinion, businesses in the fashion industry, through their environmental behavior and the offers of circular solutions, can significantly influence consumers' purchasing decisions. At first sight, businesses decide on offers consumers can choose from. However, finally, the consumer decides whether he will respond to these business suggestions, whether he will accept products' characteristics as well as the proposed price. On this basis, there is an opportunity to examine the consumers' behavior and attitudes to the "environmental" stimuli of fashion manufacturers and sellers in the circular models' field.

\section{RESEARCH OBJECTIVE, METHODOLOGY AND DATA}

The paper deals with the Slovak consumers' behavior related to the implementation of circular economy principles in the fashion industry. The main aim of the paper is to examine consumer attitudes towards the new circular models in the fashion industry (e.g. slow fashion, swapping, clothes rent, etc.), knowledge of these models, willingness to support them, and correlation to the selected demographic characteristics. Exploring various aspects of consumer behavior is important for businesses that want to respond to the desires and expectations of environmentally 
responsible consumers by offering circular solutions. Offering sustainable models reflecting CE principles can help businesses to differentiate themselves from competitors in the globalized market. A partial aim of our research was set - to examine consumer attitudes towards the textile products made of waste material, consumers' motives and barriers in the buying process, and acceptance of price for these products.

To fulfill the aims of the paper, there were conducted two kinds of researches, namely the secondary data analysis and primary quantitative consumer research. While processing the literature review focused on describing the issue of the paper, several theoretical scientific methods were applied. Consumer research has been carried out to gain data depicting various aspects of consumer behavior, awareness, and attitudes concerning circular economy principles implementing in the fashion industry. Data were collected in October and November 2019 via an online questionnaire. The questionnaire contained 26 questions in four sections. The first part was oriented on environmental awareness in general; the second one was on circular economy principles using in consumer behavior. The content of the third section was focused on the new circular models in the fashion industry and buying textile products. The last part of the questionnaire served to find out selected socio-demographic data about the respondents. When constructing the questionnaire, various types of questions were utilized, mainly closedended questions (dual and multiple-choice response options) and Likert scale questions. The gained survey data were processed by using Excel software and then analyzed by software SPSS (Statistical Package for Social Sciences) by applying various statistical tests (binomial test, Chisquare test, Wilcoxon test, Spearman test).

In the paper, only selected results from the first section (two questions about CE awareness) and the third section (seven questions relating to circular models in the fashion industry) are presented. Based on a theoretical review, international studies, and previous research on environmentally responsible consumer behavior in Slovakia and the context of the main aim of the paper, we assumed the following:

1. Respondents who know the new economic model (circular economy) are more willing to support new circular models in the fashion industry.

2. The youngest respondents (generation Z) are more willing to support new circular models.

3. There is a significant influence of gender on willingness to support new circular models.

4. The environmental factors influencing buying clothes made from waste or recycled materials are more important for women than for men.

5. Younger consumers are more willing to pay more for products made from waste materials.

Assumptions of correlations of respondents' willingness to support new models in the fashion industry with their knowledge of $\mathrm{CE}$ and with age and gender were firstly verified by the Chisquare tests. Fisher's exact test was used if the assumptions of Chi-square tests concerned expected values were not fulfilled. These tests are used for the testing of independence between qualitative variables. For the Chi-square test and Fisher's exact test, the following statistical hypotheses were formulated in general:

HOA: analyzed characters are independent. 
H1A: analyzed characters are dependent.

Then the intensity of the coefficients was computed by Spearman's correlation coefficient (for the dependency of ordinal variables), Cramer's V, and Pearson's contingency coefficient (for the dependency of nominal variable and ordinal variable). The intensity of the dependence marked by Cramer's V and Pearson contingency coefficient is assessed according to this scale:

$0.0<$ the value of the coefficients $\leq 0.3$ weak dependence,

$0.3<$ the value of the coefficients $\leq 0.8$ medium dependence,

$0.8<$ the value of the coefficients $\leq 1.0$ strong dependence.

The scale of dependencies is the same for Spearman's correlation coefficient, but it is necessary to use absolute values of the coefficient.

The following statistical hypotheses were used to testing of the significance of used coefficients: H0B: the coefficient is statistically insignificant.

H1B: the coefficient is statistically significant.

Overall, 468 respondents participated in the questionnaire survey. The basic sample consisted of all active inhabitants in Slovakia born from 1946 to 2001 (only respondents older than 18 years were included in the survey sample). The research sample follows the structure of the Slovak population (according to the Statistical Office SR in the research period; 4,066,178 people) in terms of gender and age. To achieve the representativeness of the research (with the possibility to generalize the findings), quota sampling in terms of gender and age was chosen. The representativeness of the sample according to the mentioned demographic features through the Chi-square test was verified ( $\mathrm{p}$-value gender 0.408, p-value age/generation 0.088; at the significance level $\alpha=0.05$ ) (Table 1).

Tab. 1 - Research Sample (Test on Representativeness included). Source: own research

\begin{tabular}{|l|l|l|l|}
\hline Gender & Observed N & Expected N & Residual \\
\hline Female & 245 & 236.1 & 8.9 \\
\hline Male & 223 & 231.9 & -8.9 \\
\hline Total & 468 & & \\
\hline \multicolumn{2}{|l|}{ Test Statistics } & \multicolumn{2}{l|}{} \\
\hline Chi-Square & \multicolumn{2}{|l|}{} & Gender \\
\hline Df & & & $.683 a$ \\
\hline Asymp. Sig. & Observed N & Expected N & Residual \\
\hline Age & 136 & 149.4 & -13.4 \\
\hline Baby Boomers & 100 & 96.4 & 3.6 \\
\hline Generation X & 169 & 17.7 & -5.7 \\
\hline Generation Y & 63 & 47.5 & 15.5 \\
\hline Generation Z & 468 & & \\
\hline Total & & & \\
\hline
\end{tabular}




\begin{tabular}{|l|l|l|l|}
\hline Test Statistics & & Age \\
\hline Chi-Square & & $6.537 \mathrm{~b}$ \\
\hline df & & 3 \\
\hline Asymp. Sig. & & .088 \\
\hline
\end{tabular}

There were 245 (52\%) women and $223(48 \%)$ men in the research sample. The least represented were respondents of Generation Z (born 1995 - 2001; aged 18+) (14\%). On the contrary, the most significant part of the sample were respondents of Generation Y (born 1977 - 1994; 36\%). The third group consisted of respondents of Generation X (born 1966 - 1976; 21\%), the fourth of respondents of Baby Boomers (born 1946 - 1965; 29\%). Besides that, other socio-demographic data were collected (education, income, place of residence (city/village), but the representativeness in those has not been confirmed. Regarding the highest level of education achieved, $42 \%$ of respondents had high school education, followed by respondents with university education (master's and $\mathrm{PhD}$. degree $-26 \%$ ). Considering the net monthly income of an individual, the largest groups consisted of respondents with an income between 700 and 999 EUR (28\%) and $500-699$ EUR (27\%). Up to $35 \%$ of respondents live in rural areas, $27 \%$ in smaller cities, and $32 \%$ in larger cities.

\section{RESULTS AND DISCUSSION}

For reasonable and responsible consumer decision-making, it is essential to have sufficient relevant information about the offers. Table 2 illustrates research results about respondents' knowledge and the willingness to support new circular fashion models (e. g., to engage in person). Respondents were asked through the five-point Likert scale to present their attitudes. For easier data processing, positive answers (yes, rather yes) and negative answers (rather no, no) were cumulated.

Tab. 2 - Knowledge and willingness to support new circular models. Source: own research

\begin{tabular}{|c|c|c|c|c|c|c|c|c|c|}
\hline & & 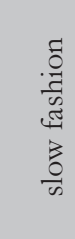 & 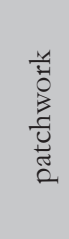 & 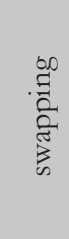 & 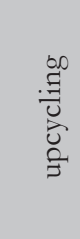 & 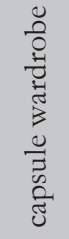 & 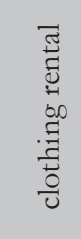 & 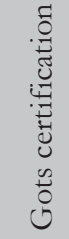 & 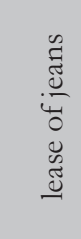 \\
\hline \multirow{3}{*}{ Knowledge } & $\begin{array}{l}\text { Yes/rather } \\
\text { yes }\end{array}$ & 209 & 207 & 197 & 194 & 128 & 96 & 69 & 31 \\
\hline & $\begin{array}{l}\text { No/rather } \\
\text { no }\end{array}$ & 241 & 245 & 259 & 252 & 323 & 357 & 361 & 415 \\
\hline & Neutral & 18 & 16 & 12 & 22 & 17 & 15 & 38 & 22 \\
\hline
\end{tabular}




\begin{tabular}{|l|l|l|l|l|l|l|l|l|l|}
\hline \multirow{2}{*}{$\begin{array}{l}\text { Willingness } \\
\text { to support }\end{array}$} & $\begin{array}{l}\text { Yes/rather } \\
\text { yes }\end{array}$ & $\mathbf{3 6 0}$ & $\mathbf{3 0 9}$ & $\mathbf{3 0 7}$ & $\mathbf{3 5 0}$ & $\mathbf{2 8 0}$ & $\mathbf{1 8 4}$ & $\mathbf{2 9 2}$ & $\mathbf{1 0 1}$ \\
\cline { 2 - 10 } & $\begin{array}{l}\text { No/rather } \\
\text { no }\end{array}$ & 81 & 122 & 144 & 88 & 160 & 253 & 126 & 330 \\
\cline { 2 - 10 } & Neutral & 27 & 37 & 17 & 30 & 28 & 31 & 50 & 37 \\
\hline
\end{tabular}

Respondent's willingness to support new circular models in Slovakia is higher than the knowledge of them in all eight cases. Some researchers (e. g., Paco et al., 2020; Yee et al., 2016) also confirmed limited awareness of sustainable clothing and circular consumption. Other studies (Ritch, 2020; Wiederhold et al., 2018) focused on introducing sustainable models found out similarly that even though participants showed some sustainable behaviors, the awareness of fashion sustainability/circularity was low. There is a range of circular fashion business models and consumer perception can vary in individual cases. However, the awareness of circularity can positively influence consumer responsible behavior and consumption in the fashion market.

According to the preferences of respondents, there are three models with the highest potential (willingness to support) - Slow fashion, Upcycling, Patchwork. Wilcoxon test, which determines whether there is a statistically significant difference between the individual concepts (in pairs, in order), confirmed that willingness to support slow fashion and upcycling is the same (p-value 0.959), in the case of upcycling and patchwork different ( $p$-value 0.045). The willingness of respondents in our study corresponds to the research by Gazzola et al. (2020), which argues less importance is attached to ownership. More and more consumers (especially younger), according to Lang et al. (2019), prefer renting clothes rather than buying them. Paco et al. (2020) found positive attitudes towards donation and swapping with family and friends as well as in terms of clothing reuse and second-hand buying.

To get an overview of significant dependencies (between willingness to support new models and awareness of CE model, age, and gender), the analysis only in the case of three models with the highest potential was performed. According to statistical results in Table 3, at the level of significance $\alpha=0.05$, we accept assumption 1 , which means there is a significant dependency between the willingness to support new three models in the fashion industry and knowledge of the circular economy (CE awareness) confirmed by Fisher's exact. According to Spearman correlation coefficient, correlation is significant, weak, and direct. In general, only $38.7 \%$ of all respondents had an idea of what the $\mathrm{CE}$ model means $(9.2 \%$ of respondents exactly know what $\mathrm{CE}$ is). Most of the respondents (61.4\%) have never heard about CE $(36.8 \%)$ or have no idea what it means $(24.6 \%)$. More detailed percentages show that between men and women are no significant differences in their awareness.

Tab. 3 - Statistical results - correlations. Source: own research

\begin{tabular}{|l|c|c|c|}
\hline \multicolumn{1}{|c|}{ CE awareness } & Slow fashion & Upcycling & Patchwork \\
\hline Test of independence & Fisher's exact & Fisher's exact & Fisher's exact \\
\hline p-value & 0.003 & 0.006 & 0.002 \\
\hline Spearman Correlation Coefficient & 0.143 & 0.128 & 0.147 \\
\hline
\end{tabular}




\begin{tabular}{|l|c|c|c|}
\hline p-value & 0.003 & 0.006 & 0.002 \\
\hline Age & Slow fashion & Upcycling & Patchwork \\
\hline Test of independence & Fisher's exact & Fisher's exact & Fisher's exact \\
\hline p-value & 0.000 & 0.248 & 0.844 \\
\hline Spearman Correlation Coefficient & -0.120 & - & - \\
\hline p-value & 0.009 & - & - \\
\hline Gender & Slow fashion & Upcycling & Patchwork \\
\hline Test of independence & Chi-square & Chi-square & Chi-square \\
\hline p-value & 0.000 & 0.000 & 0.000 \\
\hline Cramer's V & 0.244 & 0.217 & 0.225 \\
\hline p-value & 0.000 & 0.000 & 0.000 \\
\hline Pearson's Contingency Coefficient & 0.237 & 0.212 & 0.220 \\
\hline p-value & 0.000 & 0.000 & 0.000 \\
\hline
\end{tabular}

According to Fisher's exact test and computed p-value, there is a dependency between the willingness to support slow fashion and age. Spearman correlation coefficient sets that correlation is weak, indirect, and statistically significant. On the other hand, a dependency between the willingness to support upcycling and patchwork and age was not confirmed. In the case of gender, based on the comparison of the level of significance $\alpha=0.05$ and identified p-value of the Chi-square test, we rejected the null hypothesis. Thus, we accepted the alternative hypothesis that there is a dependency between willingness to support new models and gender. The weak significant dependence was confirmed by Cramer's V and Pearson's Contingency Coefficient (Table 3).

As mentioned above, especially younger consumers are proving to be highly sensitive to social and environmental issues and their purchasing is influenced by principles of sustainability and CE. Besides that, future key consumers of generation Z (also surveyed in our research, 14\%) are characterized by higher environmental awareness and buying environmental products. When their awareness will rise, even more businesses offering products and services with environmental benefits will gain a significant competitive advantage in the following years. Based on the research results, it is evident that consumers in Slovakia need to be more informed about new circular possibilities to reuse or recycle textile products. One of the recommendations for the businesses is the need to differentiate between younger and older consumer segments as well as male and female consumers in the process of creating the marketing strategy for the new circular offering.

To meet the second partial aim of the paper, four selected influencing factors regarding respondents' attitudes and purchasing clothes made from waste or recycled materials were examined. According to research results, the important factors influencing purchasing clothes made from waste/recycled materials were health safety ( $93 \%)$, natural fabrics and materials $(86 \%)$, and local production $(60 \%)$. On the other hand, non-colored textiles were not important for half of the surveyed consumers. The importance of health safety on textile made from waste materials is also mentioned by Paco et al. (2020). Using natural fabrics and materials (e. g., organic cotton) 
as well as recycled materials can reduce the overall negative environmental impact (Nam et al., 2017). Sanad (2016) states that foreign-made products are better perceived by some consumers than the locally made ones. However, local production causes less environmental pollution and less waste.

Tab. 4 - Factors influencing buying clothes regarding gender. Source: own research

\begin{tabular}{|l|l|l|l|l|}
\hline Gender & Health safety & $\begin{array}{l}\text { Natural fabrics, } \\
\text { materials }\end{array}$ & Local production & $\begin{array}{l}\text { Non-colored } \\
\text { textiles }\end{array}$ \\
\hline Test of independence & Fisher's exact & Fisher's exact & Chi-square & Chi-square \\
\hline p-value & 0.642 & 0.014 & 0.386 & 0.002 \\
\hline Cramer's V & - & 0.130 & - & 0.164 \\
\hline p-value & - & 0.014 & - & 0.002 \\
\hline $\begin{array}{l}\text { Pearson's Contingency } \\
\text { Coefficient }\end{array}$ & - & 0.130 & - & 0.162 \\
\hline p-value & - & 0.014 & - & 0.002 \\
\hline
\end{tabular}

The significant differences in results considering gender and age were not found. However, for women, environmental factors were slightly more important than for men. We cannot reject the null hypothesis that there is no dependence between gender and health safety based on the p-value of Fisher's exact from Table 4. On the contrary, a dependency between gender and natural fabrics and materials exists. Used coefficients are significant and mark weak dependence. The Chi-square test disclosed no significant dependence between gender and local production. The final testing between gender and non-colored textiles confirmed a dependency. Cramer's $\mathrm{V}$ and Pearson's Contingency Coefficient determine significance and mark weak dependence between these variables.

Furthermore, respondents were asked if they would buy products made of waste materials (naturally, if they meet the standards, are fully fit for wear, and are not harmful to human health). $76 \%$ of research respondents answered positively. The most occurred answer were products made from recycled textiles (395 respondents with positive answers). As for products made from plastic waste, 370 respondents would buy these and 297 respondents would buy products made from recycled PET bottles. In this case, it is thought how important factor influencing consumer buying behavior ("waste made" products) is material (PET bottles/plastic or textile waste) or the type of the final product (swimsuit/wallet/backpack). The type of textile product (swimsuit) is for consumers very important, especially due to the direct contact of the fabric with skin. Generally, positive consumer attitudes towards circular products such as recycled or upcycled goods are found in a study by Park \& Lin (2020). Our respondents also showed a positive attitude - willingness to buy. Nevertheless, a positive attitude does not always positively influence "green" buying behavior. Some consumers may perceive recycled products negatively in terms of lower quality (Essoussi \& Linton, 2010). Other factors, e. g., product type, type of waste material (Magnier et al., 2019), reduced availability, economic risk, can influence environmentally responsible consumer behavior, and according to mentioned study (Park \& Lin, 2020), these factors are essential just for recycled and upcycled fashion products. According 
to a survey by Meng \& Leary (2020), consumers from Poland, France, and Spain perceived a T-shirt made from recycled plastic bottles as contaminated. In contrast, a carrying bag was not negatively evaluated. Similarly, in Slovenia, negative attitudes toward buying second-hand apparel were identified (Zurga et al., 2015).

Besides the other important factors mentioned influencing the purchase of clothes, the motivation for as well as barriers of consumers in Slovakia in terms of the CE model were explored. The strongest motivations to buy a product made of waste or recycled material were: (1) the effort to help solve perceived global environmental problems (322 respondents, $60 \%$; respondents in generation $\mathrm{Y}$ and $\mathrm{Z}$ preferred this motivation) and (2) the support of a business idea with good intentions (200 respondents, 42\%). Mayasari \& Haryanto (2018) declare different motives for people to accept new circular offerings - economic benefits, exclusivity of ownership, social bonds and networking, emotional and ecological aspects as well as personal values. A study by Singh et al. (2019) in the UK found several perceived benefits of upcycling - economic and environmental profits followed by enjoyment, fun, and feel-good reasons. In Korea (Shim et al., 2018), the indicated benefits of recycling were the positive impact on the environment by reducing waste, economic saving, long time wear as well as emotional satisfaction during and after recycling practice. Analyzing in detail results regarding respondent motives, an interesting finding was the difference between answers of men and women. The second most chosen answer for men was to support a business idea with good intentions ( $24 \%$ of men), but for women, the interest in ecological products $(22 \%)$. This finding could be interesting for creating marketing strategies for businesses in the fashion industry. In our opinion, fashion businesses will need to differentiate advertising messages for women and men when promoting new circular models.

The barriers against and obstacles related to buying textile products made of waste or recycled material were also surveyed. The strongest barrier for respondents was distrust in health safety (322; $68 \%$ ). This result again confirms previous findings - when considering a new model of selling/ buying products made of waste which could be an effective solution for current environmental problems, for excessive use of natural resources and problems with waste accumulation, the biggest challenge will be changing the attitudes and thinking stereotypes of consumers. In our view, for this radical change, people need to get the right information at the right time from the relevant source. Relatedly, the second biggest barrier was the lack of information $(200 ; 42 \%)$. Similar results were obtained in all the surveyed generations. According to Tu \& $\mathrm{Hu}$ (2018), consumers are not afraid of new offerings; they have sufficient economic capacity and a positive attitude to the innovations. In the consumer acceptance process, all barriers and doubts need to be removed, after which the willingness to use new models is presumed.

Recycled/upcycled products or products made from waste material affect the consumer evaluation of the product characteristics and thus consumer willingness to pay for these products. A significant part of research respondents $(175 ; 37 \%)$ indicated that they would purchase a product made of waste only for the same price as for competitive products without environmental idea. Almost one-third of respondents (139; 29\%) would pay 10\% more, twenty percent (94) would pay 20\% more. Almost ten percent (43 respondents) of respondents are not interested in price in considering purchasing a product made from waste. In the context of price, the Chi-square test confirmed a dependency between price and age, in which a weak, direct and 
significant correlation between price and age category was identified ( $\mathrm{p}$-value $=0.003$, Spearman correlation coefficient $=0.135$ ). Based on these results, it can be stated that younger respondents are willing to pay more for products made from waste materials (assumption 5). The willingness of men and women in our survey was similar. In general, $77 \%$ of EU citizens are willing to pay somewhat more for environmentally friendly products, although $20 \%$ are not willing to do so. The most willing were citizens in Austria, Sweden, and Germany, contrary to the least willing in Lithuania and Portugal (European Commission, 2013). Recent studies (Jalil \& Shaharuddin (2019); Chang \& Watchravesringkan (2018)) have shown that purchase intentions of clothes and textile products are influenced in particular by quality, price, and design. Consumers are not willing to purchase fashion products made of recycled materials if the price exceeds more than similar substitutes. It is recommended that products made of recycled or waste materials should have a reasonable price - equal to or lower than the competitive "virgin" products. Findings by White et al. (2019), however, oppose this idea, stating that the overall will to pay extra for sustainable offerings exists with about $2 / 3$ of customers worldwide, which was confirmed in our research by $63 \%$ surveyed.

\section{CONCLUSION}

With the rising concern over environmental sustainability, the fashion industry, which generates a substantial environmental footprint, faces major environmental and resource challenges. Aiming at the future generations, it is beginning to move towards the new circular economy (CE) model. This significant shift requires the participation of all market subjects, especially consumers, businesses, and governments. The increased demand of consumers for products with environmental characteristics is a driving force for businesses to act more responsibly and to show their activities as more circular.

The research in this paper aimed to examine consumer attitudes towards and knowledge of the selected circular fashion models as well as the willingness of consumers to support them. Reflecting the needs, expectations, and behavior of environmentally friendly consumers is crucial for businesses to create new competitive advantages based on circular solutions. To execute the main aim, a questionnaire survey was conducted to obtain data depicting consumer behaviors and attitudes concerning the implementation of CE principles in the fashion industry.

The research results show that the respondents' indicated willingness to support new circular models in the fashion industry is higher than their awareness (knowledge). Slow fashion, upcycling, and patchwork are three models with the highest potential according to consumer preferences. A correlation between the willingness to support circular models and gender was confirmed, while in terms of gender this was shown only for slow fashion. It can be stated that Slovak consumers need to be more informed about new possibilities to reuse or recycle textile products. This will likely raise their willingness to engage in the new circular models on the market and support them. The main recommendation is to raise consumer awareness regarding environmental issues by improving consumer education and increasing access to relevant information focused on pro-environmental behaviors.

Regarding consumer willingness to buy a textile product made of waste or recycled material, three-quarters of the respondents answered positively. Almost two-thirds of the respondents 
would pay for such a product at a higher price than for a competitive product without environmental idea, with younger consumers even more willing to do so. The growing attention of the younger generations ( $\mathrm{Y}$ and $\mathrm{Z}$ ) towards $\mathrm{CE}$ was found. To conclude, our research results assert that consumers can play a vital role in adopting of the CE model in practice. Their environmental requirements affect business offers of products and services. Adequate response from consumers could significantly increase the competitiveness of businesses. Our preliminary research only provides a basic view regarding the adoption of new circular fashion models in Slovak conditions. These results will be useful for a further, more detailed examination of environmentally responsible behavior of consumers as well as businesses.

The research was limited to the selected aspects of consumer behavior towards new circular models in the fashion industry in one country only. This was an initial examination concerning the novelty of the topic and the limited circular fashion offers of businesses for consumers in Slovakia as how the situation stands today. The results showed a variety of perspectives and views on sustainable and circular behavior as well as influencing factors that deserve further attention. The authors' ambition is to design and carry out a more extensive comparative survey, both in terms of content and size of respondents' sample, at least in the Central European context. In addition, another research study on fashion business practices in the context of circularity has been planned and will be conducted in a few weeks. Studies and research by various authors worldwide also serve as a direct inspiration.

\section{Acknowledgment}

This research paper was processed within the frame of project VEGA 1/0705/19 "The responsibility of selected market entities as a significant determinant for application of circular economy principles in Slovakia."

\section{References}

1. Bianchi, C., \& Birtwistle, G. (2012). Consumer clothing disposal behaviour: a comparative study. International Journal of Consumer Studies, 36 (3), 335-341. https://doi.org/10.1111/j.14706431.2011.01011.x

2. Camacho-Otero J., Pettersen, I. N., \& Boks, C. (2019). Consumer engagement in the circular economy: Exploring clothes swapping in emerging economies from a social practice perspective. Sustainable development, 28 (1), 279-293.

3. Essoussi, L. H., \& Linton, J. D. (2010). New or recycled products: how much are consumers willing to pay? Journal of Consumer Marketing, 27 (5), 458-468. https://doi. org $/ 10.1108 / 07363761011063358$

4. European Commission. (2013) Flash Eurobarometer 367. Attitudes of Europeans Towards Building Single Market For Green Products. Retrieved November 9, 2020, from http:// ec.europa.eu/public_opinion/flash/fl_367_en.pdf

5. Fell, D., Austin, A., Kivinen, E., \& Wilkins C. (2009). The diffusion of environmental behaviours; the role of influential individuals in social networks. Report 2: The evidence A report to the Department for Environment, Food and Rural Affairs. London: Defra, Brook Lyndhurst.

6. Fisher, C., Bashyal, S., \& Bachman, B. (2012). Demographic impacts on environmentally friendly purchase behaviors. Journal of Targeting, Measurement and Analysis for Marketing, 20 (3-4), 172-184. 
7. Gaustad, G., Krystofik, M., Bustamante, M., \& Badami, K. (2018). Circular economy strategies for mitigating critical material supply issues. Resources, Conservation and Recycling, 135, 24-33. https://doi.org/10.1016/J.RESCONREC.2017.08.002.

8. Gazzola, P., Pavione, E., Pezzetti, R., \& Grechi, D. (2020). Trends in the Fashion Industry. The Perception of Sustainability and Circular Economy: A Gender/Generation Quantitative Approach. Sustainability, 12 (7), 2809. https://doi.org/10.3390/su12072809

9. Grebosz-Krawczyk, M., \& Siuda, D. (2019). Attitudes of young European consumers toward recycling campaigns of textile companies. Autex Research Journal, 19, 394-399. https://doi. org/10.1515/aut-2018-0057

10. Haanpää, L. (2007). Consumers' Green Commitment: Indication of a Postmodern Lifestyle? International Journal of Consumer Studies, 31 (5), 478-486.

11. Han, J., Seo, Y., \& Ko, E. (2017). Staging luxury experiences for understanding sustainable fashion consumption: A balance theory application. Journal of Business Research, 74, 162-167. http://dx.doi.org/10.1016/j.jbusres.2016.10.029

12. Henninger, C. E., Bürklin, N., \& Niinimäki, K. (2019). The clothes swapping phenomenon when consumers become suppliers. Journal of Fashion Marketing and Management, 23 (2), 327-344. http://dx.doi.org/10.1108/JFMM-04-2018-0057

13. Henninger, C. E., \& Singh, P. (2017). Ethical Consumption patterns and the link to purchasing sustainable fashion. Henninger, C. E. et al. (Eds). Sustainability in Fashion: A Cradle to Upcycle Approach, Palgrave Macmillan, 103-126. http://dx.doi.org/10.1007/978-3319-51253-2

14. Chang, H. J., \& Watchravesringkan, K. (2018). Who are sustainably minded apparel shoppers? An investigation to the influencing factors of sustainable apparel consumption. International Journal of Retail \& Distribution Management, 46 (2), 148-162.

15. Chekima, B., Wafa, S. A., Igau, O. A., Chekima, S., \& Sondoh Jr., S. L. (2016). Examining green consumerism motivational drivers: do premium price and demographics matter to green purchasing? Journal of Cleaner Production, 112, 3436-3450.

16. Jalil, M. H., \& Shaharuddin, S. S. (2019). Consumer Purchase Behavior of Eco-Fashion Clothes As a Trend to Reduce Clothing Waste. International Journal of Innovative Technology and Exploring Engineering, 8 (12), 4224-4233. https://doi.org/10.35940/ijitee.L2693.1081219

17. Kirchherr, J., Piscicelli, L., Bour, R., Kostense-Smit, E., Muller, J., Huibrechtse-Truijens, A., \& Hekkert, M. (2018). Barriers to the Circular Economy: Evidence From the European Union (EU). Ecological Economics, 150, 264-272. https://doi.org/10.1016/j.ecolecon.2018.04.028

18. Kusa, A., \& Greskova, P. (2016). Marketingová komunikácia v kontexte hodnôt a nákupného správania generácie 50+. Trnava: UCM.

19. Lang, C., Seo, S., \& Liu, C. (2019). Motivations and obstacles for fashion renting: A crosscultural comparison. Journal of Fashion Marketing and Management, 23 (4), 519-536. https://doi. org/10.1hen108/JFMM-05-2019-0106

20. Liobikienė, G., Grincevičienè, Š., \& Bernatonienė, J. (2017). Environmentally friendly behaviour and green purchase in Austria and Lithuania. Journal of Cleaner Production, 142, 3789-3797. https://doi.org/10.1016/j.jclepro.2016.10.084 
21. Magnier, L., Mugge, R., \& Schoormans, J. (2019). Turning ocean garbage into products Consumers' evaluations of products made of recycled ocean plastic. Journal of Cleaner Production, 215, 84-98. https://doi.org/10.1016/j.jclepro.2018.12.246

22. Mayasari, I., \& Haryanto, H. CH. (2018). Motivational Factors of Collaborative Consumption in The Era of Sharing Economy. Gadjah Mada International Journal of Business. 20(3). https://doi. org/10.22146/gamaijb. 27552

23. Meng, M. D., \& Leary, R. B. (2019). It might be ethical, but I won't buy it: Perceived contamination of, and disgust towards, clothing made from recycled plastic bottles. Psychology \& Marketing, 38(2), 298-312. https://doi.org/10.1002/mar.21323

24. Mugge, R. (2018). Product design and Consumer Behaviour in a Circular Economy. Sustainability, 10 (10), 3704.

25. Musova, Z., Musa, H., \& Matiova, V. (2021). Environmentally responsible behaviour of consumers: Evidence from Slovakia. Economics and Sociology, 14 (1), 178-198. https://doi. org/10.14254/2071-789X.2021/14-1/12

26. Nam, Ch., Dong, H., \& Lee, Y. A. (2017). Factors influencing consumers' purchase intention of green sportswear. Fashion and Textiles, 4 (2). https://doi.org/10.1186/s40691-017-0091-3

27. Paco, A., Leal Filho, W., Ávila, L. V., \& Dennis, K. (2020). Fostering sustainable consumer behavior regarding clothing: Assessing trends on purchases, recycling and disposal. Textile Research Journal, 91(3-4), 373-384. https://doi.org/10.1177/0040517520944524

28. Paras, M. K., Curteza, A., \& Pal, R. (2019). A Romanian case study of clothes and accessories upcycling. Industria textila, 70 (3).

29. Park, H. J., \& Lin, L. M. (2020). Exploring attitude-behavior gap in sustainable consumption: Comparison of recycled and upcycled fashion products. Journal of Business Research, 117, 623-628. https://doi.org/10.1016/j.jbusres.2018.08.025

30. Riba, J. R., Cantero, R., Canals, T., \& Puig, R. (2020). Circular economy of post-consumer textile waste: Classification through infrared spectroscopy. Journal of Cleaner Production, 272, 123011. https://doi.org/10.1016/j.jclepro.2020.123011

31. Ritch, E. L. (2020). Experiencing fashion: the interplay between consumer value and sustainability. Qualitative Market Research, 23 (2), 265-285. https://doi.org/10.1108/QMR-092019-0113

32. Sanad, R. A. (2016). Consumer Attitude and Purchase Decision towards Textiles and Apparel Products. World Journal of Textile Engineering and Technology, 2, 16-30.

33. Shim, S., Kim, J., \& Na, Y. (2018). An exploratory study on up-cycling as the sustainable clothing life at home. Fashion and Textiles, 5 (14).

34. Singh, J., Sung, K., Cooper, T., West., K., \& Mont, O. (2019). Challenges and opportunities for scaling upcycling businesses - The case of textile and wood upcycling businesses in the UK. Resources, Conservation \& Recycling, 150.

35. Souchet, F. (2019). Fashion has a huge waste problem. Here's how it can change. World Economic Forum. Retrieved November 10, 2020, from https://www.weforum.org. 
36. Suárez-Eiroa, B., Fernández, E., Méndez-Martínez, G., \& Soto-Onate, D. (2019). Operational principles of circular economy for sustainable development: Linking theory and practice. Journal of Cleaner Production, 214, 952-961. https://doi.org/10.1016/j.jclepro.2018.12.271

37. Tu, J., \& Hu, Ch. (2018). A Study on the Factors Affecting Consumers' Willingness to Accept Clothing Rentals. Sustainability. 10 (11), 1-30.

38. Ulku, M. A., \& Hsuan, J. (2017). Towards sustainable consumption and production: competitive pricing of modular products for green consumers. Journal of Cleaner Production,142, $4230-4242$.

39. Wei, S., Ang, T., \& Jancenelle, V. E. (2018). Willingness to pay more for green products: the interplay of consumer characteristics and customer participation. Journal of Retailing and Consumer Service, 45, 230-238. https://doi.org/10.1016/j.jretconser.2018.08.015

40. White, K., Habib, R., \& Hardisty, D. J. (2019), How to shift Consumer Behaviors to be More Sustainable: A Literature Review and Guiding Framework. Journal of Marketing, 83 (3), 22 - 49.

41. Wiederhold, M., \& Martinez, L. F. (2018). Ethical consumer behaviour in Germany: The attitude-behaviour gap in the green apparel industry. International Journal of Consumer Studies, 42, 419-429. https://doi.org/10.1111/ijcs.12435

42. Yee, L.W., Hassan, S.H., \& Ramayah, T. (2016). Sustainability and philanthropic awareness in clothing disposal behavior among young Malaysian consumers. Sage Open, 6 (1). https://doi. org $/ 10.1177 / 2158244015625327$

43. Zurga, Z., Hladnik, A., \& Tavcer, P.F. (2015). Environmentally sustainable apparel acquisition and disposal behaviours among Slovenian consumers. Autex Research Journal, 2015, 15, 243-259. https://doi.org/10.1515/aut-2015-0044

\section{Contact information}

prof. Ing. Zdenka Musova, PhD.

Matej Bel University in Banská Bystrica,

Faculty of Economics, Department of Corporate Economics and Management

Slovakia

E-mail: rdenka.musova@umb.sk

ORCID: 0000-0002-1067-8291

prof. Ing. Hussam Musa, PhD.

Matej Bel University in Banská Bystrica

Faculty of Economics, Department of Finance and Accounting

Slovakia

E-mail: hussam.musa@umb.sk

ORCID: 0000-0002-4492-8770

Ing. Jennifer Drugdova

Matej Bel University in Banská Bystrica

Faculty of Economics, Department of Corporate Economics and Management

Slovakia

E-mail:jennifer.drugdova@umb.sk. 
assoc. prof. George Lazaroiu, PhD.

Spiru Haret University

Faculty of Social and Human Sciences, Department of Social Human Sciences

Romania

E-mail:phd_lazaroin@yahoo.com

ORCID: 0000-0002-3422-6310

Jehad Alayasa, Ph.D.

Birzeit University in Birzeit

Faculty of Law and Public Administration, Department of Public Administration

Palestine

E-mail:jalayasa@birzeit.edu

ORCID: 0000-0002-9929-7427 